to June. ${ }^{1}$ The evidence that the lynx was able to lift the entire beaver carcass from time to time also suggests the beaver was not a mature individual.

1. BOYLE, S. and S. OWEN. 2007. North American Beaver (Castor canadensis): A Technical Conservation Assessment, February 6, 2007. Prepared for USDA Forest Service, Rocky Mountain Region, Species Conservation Project. Available via the Internet at http://www.fs.fed.us/r2/projects/scp/assessments/ northamericanbeaver.pdf.

2. COOK, A. and E. MAUNTON. 1954. A study of the criteria for estimating the age of beavers. New York Fish and Game Journal 1:27-46.
3. MOWAT, G., K. POOLE, and M. O'DONOGHUE. 1999. Ecology of Lynx in Northern Canada and Alaska. In: Ecology and Conservation of Lynx in the United States, USDA General Technical Report RMRS-GTR-30WWW. Available via the Internet at http://www.fs.fed.us/rm/pubs/rmrs_gtr030/rmrs_ gtr030_265_306.pdf.

4. REZENDES, P. 1992. Tracking and the Art of Seeing. Camden House Publishing Inc., Rochester, New York.

- Ken Kingdon, Box 314, Onanole, MB, R0J 1N0; E-mail:<ken.kingdon@pc.gc. ca>

\title{
BLACK-CAPPED CHICKADEES AND WHITE-BREASTED NUTHATCHES SCAVENGE A DEER CARCASS
}

The carcasses of mid-sized to large animals comprise a high quality food resource for both predatory and omnivorous animals, especially during the winter months when few other food resources may be readily available. A number of our local winter birds make significant use of carcasses, including Ravens, which often are among the first animals to arrive at a carcass, and Black-billed Magpies and jays, which do best after carcasses have been opened by other animals. Black-capped Chickadees, White- and Red-breasted Nuthatches, and Hairy and Downy Woodpeckers might all be expected to scavenge carcasses, based on their use of suet feeders, but there are few well documented observations of their activities in this respect. Here we report carcass scavenging by two of the latter species.

In mid-January 2010, we found a group of three dead White-tailed Deer along the banks of the Assiniboine River just west of Winnipeg, Manitoba. The site had been visited by Coyotes, Red Foxes, and possibly local farm dogs, which had opened the carcasses and consumed about $50 \%$ of the muscle mass of the deer. While we investigated the remains, a mixed flock of Black-capped Chickadees, White-breasted Nuthatches, and a Downy Woodpecker moved into the immediate area. The chickadees showed a particular interest in the deer we were examining, repeatedly approaching it but always turning away just before landing. We stepped back several feet from the carcass to allow the birds more room. Shortly thereafter, a chickadee launched from a small shrub, landed on the exposed femur of the deer, reached under the deer's skin, and pulled off a tiny strip of muscle. After taking a few seconds to consume the small piece of meat, it reached under the deer's skin again, tore off a second piece of muscle and then flew off with the tissue in its beak. We reached for our camera and set up near the deer to try and document this activity.

Over the next 20 minutes, we observed at least five chickadees and two nuthatches repeatedly scavenging small pieces of muscle from the deer carcasses. The accompanying photographs provide documentary proof of this activity: a Black-capped Chickadee lands on a deer carcass (Fig. 1, see inside back cover, top), reaches into it and pulls off a small 
strip of muscle tissue, and then emerges with the tissue in its beak (Fig. 2, see inside back cover, bottom). The Whitebreasted Nuthatches proved too wary to be unambiguously captured in the act of scavenging with the camera equipment we had on hand, ceasing their activity and flying off each time we attempted to close within $\sim 8 \mathrm{~m}$ of their position. We did not observe the Downy Woodpecker feeding on the carcasses, but it remained in the immediate vicinity for the entire time we were present, searching the nearby trees where the chickadees and nuthatches were caching pieces of meat and fat.

Black-capped Chickadees have previously been observed scavenging skunk and deer carcasses. ${ }^{2,3}$ They are generally thought to prefer fat, ${ }^{6}$ but in our observations, muscle was the primary tissue of interest. Among closely related passerines, the Great Tit (Parus major) is similarly reported to scavenge carcasses, ${ }^{4}$ but also hunts and kills hibernating bats during periods of extreme winter weather. ${ }^{1}$ There are a few observations of woodpeckers scavenging carcasses, ${ }^{4,5}$ but we found no previous reports of carcass scavenging by Whitebreasted Nuthatches.

1. ESTÓK, P., S. ZSEBÖK and B. M. SIEMERS. 2009. Great tits search for, capture, kill and eat hibernating bats. Biology Letters. Published online before print. doi:10.1098/rsbl.2009.0611

2. GLASE, J. C. 1973. Ecology of social organization in the Black-capped Chickadee. Living Bird 12:235267.

3. HAMERSTROM, F. 1942. Dominance in winter flocks of chickadees. The Wilson Bulletin 54:32-42.

4. SELVA, N., B. J. DRZEJEWSKA, W.J. DRZEJEWSKI and A. WAJRAK. 2005. Factors affecting carcass use by a guild of scavengers in European temperate woodland. Canadian Journal of Zoology 83:15901601.

5. SERVIN, J., S. L. LINDSEY and B. A. LOISELLE. 2001. Pileated Woodpecker scavenges on a carcass in Missouri. The Wilson Bulletin 113:249-250.

6. SMITH, S. M. 1993. Black-capped Chickadee (Poecile atricapillus), The Birds of North America Online (A. Poole, Ed.). Ithaca: Cornell Lab of Ornithology; Retrieved from the Birds of North America Online: http://bna.birds.cornell.edu/bna/ species/039doi:10.2173/bna.39

- Brian R. Parker and Laurie L. Lywak, 538 Cathcart St., Winnipeg, MB, R3R 0S5

\section{SURVIVAL OF A ‘FOSTERED’YOUNG GREAT HORNED OWL}

On 10 March 2009, I captured an adult Great Horned Owl in a net near the Edmonton International Airport. The bird was previously banded (no. 788-12210), and I recorded this information as well as an assessment of the bird's condition before releasing it. Later examination of banding records indicated that I had banded this bird as a nestling on 28 May 2002. However, as this was no ordinary nestling, I will share its remarkable story in this note.

Around 5 May 2002, a flightless young owl had been found wandering on the ground in the campground at the Blood Indian Creek Reservoir about 55 mi south of Coronation, Alberta. A search for the nest by some campers found that it had blown down and no adults or young owls were observed in the area. The owlet, which had no physical injuries other than being somewhat emaciated and very hungry, was cared for and rehabilitated for 2 weeks at the nearby T.K. Ranch (by C. Biggs, a local volunteer). On 19 May 2002, I was contacted by Mrs. Biggs, who informed me that she had an abandoned Great Horned Owl nestling that needed to be returned to the wild. Fostering the young owl in another active nest would be a critical step in this process.

I regularly monitor Great Horned Owl nests in the Edmonton area in preparation for banding the young, and in 2002, there 